\title{
KULTURA WSPÓŁPRACY W SZKOLE W PERCEPCJI NAUCZYCIELI SZKÓŁ GIMNAZJALNYCH${ }^{1}$
}

\begin{abstract}
Tłuściak-Deliowska Aleksandra, Dernowska Urszula, Kultura wspótpracy w szkole w percepcji nauczycieli szkót gimnazjalnych [Middle School Teachers' Perceptions of Collaborative School Culture]. Studia Edukacyjne nr 40, 2016, Poznań 2016, pp. 127-148. Adam Mickiewicz University Press. ISSN 1233-6688. DOI: 10.14746/se.2016.40.8
\end{abstract}

School culture, more than any other single factor, determines the ultimate success or failure of any school. Undoubtedly, it is one of the indicators of school quality as well as a multifaceted concept composed of many factors. The article presents the results of the pilot study which was aimed to determine the perception of collaborative school culture by the teachers. The research was administered to middle schools' teachers in the regions of Podkarpacie and Mazovia. The quantitative research perspective was used to obtain data to validate factors such as: unity of purpose, collaborative leadership, professional development, teacher collaboration, collegial support, and learning partnership. The Polish version of the School Culture Survey inventory (S. Gruenert, J. Valentine, 1998) was used.

The results implied that teachers and school principals generally value and contribute to creating a collaborative school culture, but still do not pay as much attention as necessary to create learning partnership with parents.

Key words: school culture, school culture perception, high junior school teachers, collaborative school culture

\section{Wprowadzenie}

Kultura szkoły nie od dziś jest przedmiotem zainteresowań teoretycznych i empirycznych. O kulturze szkoły pisał już w 1932 roku Willard WalAPS.

${ }^{1}$ Artykuł przygotowano $\mathrm{w}$ ramach realizacji projektu badawczego BSTP 16A/13 - I WNP 
ler, autor The Sociology of Teaching, który zauważył, że szkoły „mają kulturę, która jest im przynależna". W literaturze pojęcie kultury szkoły wyjaśniane jest na różne sposoby: są definicje, których autorzy eksponują wartości i przekonania spajające szkolną społeczność; inni z kolei skłonni są traktować kulturę szkoły jako swego rodzaju perspektywę, z której uczestnicy tej społeczności patrzą na siebie, na innych, na rzeczywistość. Próbuje się także wyjaśnić to pojęcie poprzez odwołanie do niepisanych norm, oczekiwań, tradycji, które przenikają i determinują wszystko, a więc to, jak zachowują się ludzie, jak mówią i co mówią, jak się ubierają, czy i ewentualnie jak zwracają się do innych o pomoc, czy cenią współpracę i do niej dążą, co nauczyciele myślą o szkole, swojej $\mathrm{w}$ niej pracy i to, jak postrzegają swoich uczniów, dyrekcję i cały personel szkoły².

Douglas Fisher, Nancy Frey i Ian Pumpian uważają, że kultura szkoły nie może być ukryta, ale tak jawna i uświadomiona, jak nasze podejście do nauczania i uczenia się. Co więcej, kultury „nie tworzy się w ciągu jednej nocy bądź planując ją $\mathrm{w}$ samotności z ołówkiem w ręku" ${ }^{3}$. Wyłania się ona z wizji organizacji, wartości, przekonań, jej misji. Kultura rozwija się i wzrasta poprzez akumulację działań, tradycji, symboli, ceremonii i rytuałów, które są sprzymierzone $\mathrm{z}$ tą wizją ${ }^{4}$. Kultura - jako taka - zbudowana jest zatem wokół konfiguracji powiązanych ze sobą wierzeń, idei, postaw, wartości, sensów, znaczeń, symboli, rytuałów, czy zachowań. Należy ją bowiem rozpatrywać jako złożoną całość, system sprzęgniętych ze sobą różnych elementów ${ }^{5}$. I to właśnie „kultura, bardziej niż jakikolwiek inny pojedynczy czynnik, determinuje ostateczny sukces bądź porażkę każdej szkoły"6.

Nieustannie zmieniająca się, często w sposób nieprzewidywalny, rzeczywistość implikuje zmiany w instytucjach społecznych. Szkoła, jako instytucja, również ulega przemianom, a kultura szkoły - w zależności od tego, jaka jest - może ułatwiać bądź utrudniać jej dostosowanie do zmieniającej się rzeczywistości. Kultura szkoły z jednej strony jest źródłem stabilizacji danej placówki, z drugiej zaś umożliwia odkrywanie i dokonywanie w niej niezbędnych przeobrażeń7 ${ }^{7}$ Cel współczesnej szkoły jako instytucji zdaje się być jasny - być bardziej wydajną, efektywną i elastyczną. Warunkiem

${ }^{2}$ L.T. Schoen, C. Teddlie, A new model of school culture: a response to a call for conceptual clarity, School Effectiveness and School Improvement, 2008, 2.

${ }^{3}$ D. Fisher, N. Frey, I. Pumpian, How to Create a Culture of Achievement in Your School and Classroom, Alexandria 2012, s. 6.

4 Tamże.

${ }^{5}$ D. Tuohy, Dusza szkoty, przekł. K. Kruszewski, Warszawa 2002.

${ }^{6}$ R.D. Ramsey, Don't Teach the Canaries not to Sing, Thousand Oaks 2008, s. 2.

7 B. Przyborowska, Kultura organizacyjna oświaty w zmiennym otoczeniu, Olsztyn 2007, s. 5. 
wstępnym zmiany szkoły w posiadającą te cechy placówkę jest koncentracja na jej jakości, kreatywności, innowacyjności i zdolności do szybkich przemian oraz adaptacji do nowych warunków. Jeśli szkoła ma ów cel urzeczywistnić, potrzebne są nie tylko przekształcenia na poziomie organizacji systemu oświaty, ale także - a może przede wszystkim - wspólna praca dyrekcji, nauczycieli, uczniów i rodziców nad zmianą szkoły i w szkole, co wymaga namysłu, , analizowania i badania dlaczego ich szkoła powinna być lepszym miejscem dla wszystkich uczniów i pracowników"8. Najważniejszym zatem zadaniem dyrektorów szkół jest budowanie wizji tego miejsca, rozumienie innych (nauczycieli i uczniów) oraz dbałość o ich rozwój, przekształcanie organizacji tak, by ten rozwój umożliwiać, a także zarządzanie procesem nauczania-uczenia się w szkole. Kultura szkoły może mieć pozytywny wpływ na proces kształcenia, determinując zachowanie nauczyciela w całym procesie edukacyjnym oraz ukierunkowując działania uczniów na tworzenie pozytywnego klimatu $\mathrm{w}$ klasie szkolnej, dzięki czemu mogą w pełni wykorzystywać swój potencjał do efektywnego nabywania bądź rozwijania w trakcie lekcji tych kompetencji, na kształtowanie lub doskonalenie których proces kształcenia jest właśnie zorientowany9.

Kultura szkoły wymaga konstruowania. Jest też dynamizmem. Kulturowe ramy, określające wzorce zachowań i oczekiwań, są nieustannie budowane i przebudowywane, odkrywane, rozwijane, adoptowane i adaptowane przez wszystkich członków organizacji, jaką jest szkoła10. Kultura szkoły zapewnia jednocześnie kontekst, w którym przebiega cały proces kształcenia. $\mathrm{Z}$ tego punktu widzenia znaczenie kultury dla funkcjonowania i poprawy jakości pracy szkoły jest istotne.

\section{Kultura współpracy w szkole}

Kultura organizacyjna obejmuje założenia, postawy, zachowania, przekonania, rytuały, tradycje, wiedzę, język, normy i wszelkie wartości podzielane przez członków organizacji. Kultura szkoły poza swoją siłą oraz homogenicznością ma też swoją materię, czyli treść odnoszącą się do znaczenia podstawowych założeń, norm, wartości oraz kulturowych artefaktów, znaczenia nadawanego im przez uczestników organizacji, jaką jest szkoła oraz

8 N. Brankovic, V. Rodić, Determination of Indicators of School Culture in Primary Schools, The New Educational Review, 2012, 3, s. 46.

9 Tamże.

${ }^{10}$ R.D. Ramsey, Don't Teach the Canaries. 
przez nich podzielanego. Ta treść właśnie, będąca przedmiotem zainteresowań badaczy, często jest przez nich stratyfikowana i etykietowana, a dominacja jakiegoś wymiaru treści kultury stanowi przesłankę do uznania, że w danej szkole mamy na przykład do czynienia z kulturą "osiągnięć uczniów" , na te osiągnięcia bowiem ukierunkowane są zmiany, inicjatywy, działania szkoły. W innej natomiast szkole uobecnia się kultura „współpracy", ponieważ akcentowane są te normy, wartości, przekonania i założenia, które dotyczą współdziałania z innymi, wzajemnego wspierania się, wspólnego poszukiwania rozwiązań doświadczanych problemów, wspólnego celebrowania odnoszonych sukcesów, uczenia się z innymi i dzięki doświadczeniu innych ${ }^{11}$.

Michael G. Fullan i Andy Hargreaves wymieniają sześć cech służących do opisu szkoły jako miejsca, w którym dominuje kultura współpracy, a mianowicie: wspólne rozwiązywanie problemów i dzielenie się wiedzą na temat sztuki nauczania; funkcjonowanie silnych sieci społecznych umożliwiających przepływy profesjonalnej wiedzy i umiejętności; poszukiwanie nowych rozwiązań dydaktycznych, eksperymentowanie i podejmowanie ryzyka związanego z tymi działaniami, przy jednoczesnym wzajemnym wsparciu i dostarczaniu sobie nawzajem informacji zwrotnej; język nauczycieli pozwalający na rzeczowe porozumienie i sprawny przekaz wiedzy specjalistycznej; wyższe poczucie zawodowej satysfakcji i wyższy poziom identyfikacji nauczycieli ze szkołą; bardziej świadome i stabilne podejście do poprawy funkcjonowania szkoły, lepsze realizowanie jej misji poprzez poprawę działań personelu szkolnego' ${ }^{12}$.

W trakcie tworzenia silnej, pozytywnej kultury istotna jest wspólna troska wszystkich uczestników szkolnej wspólnoty o środowisko uczenia się czy warunki sprzyjające kształceniu. Język używany w szkole, podejmowane działania i szkolna codzienność powinny być zorientowane na tworzenie dobrych emocjonalnie warunków poznawania oraz przebywania w szkole, w której nie tylko uczniowie, ale także ich rodzice i personel czują się komfortowo, czują się w mile widziani, ważni, rozumiani. W procesie budowania kultury osiągnięć i kultury współpracy w szkole konieczna jest także troska o dobór personelu i jego rozwój, jak również koncentracja na jakości nauczania, interakcji, zarządzania - oraz cykliczna analiza i poprawa tej jakości. Misja i wizja szkoły są więc rozwijane oraz rewidowane nie tyle

\footnotetext{
${ }^{11}$ R. Maslowski, A Review of Inventories for Diagnosing School Culture, Journal of Educational Administration, 2006, 44(1).

12 Cyt. za: A.I. Gumuseli, A. Eryilmaz, The Measurement of Collaborative School Culture on Turkish Schools, New Horizons in Education, 2011, 59(2).
} 
przez działającego $\mathrm{w}$ pojedynkę dyrektora, ile przez reprezentatywną grupę osób zainteresowanych powodzeniem działalności edukacyjnej placówki ${ }^{13}$. Pracując wspólnie, nauczyciele dyskutują na temat programu, nauczania, przełamują własną zawodową izolację, dzięki czemu mogą poczuć się lepiej przygotowani do nauczania, czerpią $\mathrm{z}$ instrumentarium innych, dzielą się wiedzą i wspólnie z innymi poszukują nowych rozwiązań. Dyrektorzy szkół natomiast, by kulturę współpracy współtworzyć i pogłębiać, powinni - za pomocą określonych wartości, przekonań, postaw - promować środowisko uczenia się sprzyjające rozwojowi zawodowemu nauczycieli. Nie jest to możliwe bez budowania $\mathrm{z}$ nauczycielami relacji nacechowanych wsparciem, bez tworzenia im takich warunków pracy, by mogli doskonalić i wzbogacać repertuar dydaktycznych działań, poszukiwać i implementować nowe idee, metody i środki ${ }^{14}$. Geert Hofstede zauważa, że zachowania przywódcze, podobnie zresztą jak i teorie przywództwa, w których nie uwzględnia się oczekiwań podwładnych, są ułomne ${ }^{15}$. Teoretycy organizacji natomiast od dawna zwracają uwagę na fakt, że dbałość o kulturę jest właściwie najważniejszym działaniem, jakie lider może podjąć. Angus J. Macneil, Doris L. Prater i Steve Busch odwołują się do informacji dotyczących wypowiedzi dyrektorów renomowanych szkół, placówek doskonale urzeczywistniających swoje misje, z których jednoznacznie wynika, że koncentracja na rozwijaniu kultury szkoły jako środowiska kształcenia jest fundamentalna dla poprawy nauczycielskiego morale oraz uczniowskich osiągnięć16.

Dyrektorzy, którzy zdecydowali się raczej przewodzić niż tylko zarządzać muszą najpierw zrozumieć kulturę szkoły. Ważne jest, by uświadomić sobie, że kultura jest złożona, idiosynkratyczna, uobecnia się w różnych płaszczyznach funkcjonowania szkoły. Kiedy jasno sprecyzowany jest cel organizacji, wiadomo po co ona istnieje, jak ma działać i komu służyć, wówczas jej kultura będzie gwarantem tego, że wszystko jest tak, jak być powinno. Kiedy natomiast złożone wzorce przekonan, wartości, postaw, oczekiwań, idei i zachowań w organizacji są niespójne, wzajemnie niedostosowane, wtedy kultura takim gwarantem być nie może ${ }^{17}$.

${ }^{13}$ D. Fisher, N. Frey, I. Pumpian, How to Create a Culture of Achievement.

14 A.I. Gumuseli, A. Eryilmaz, The Measurement of Collaborative School Culture.

15 G. Hofstede, G.J., Hofstede, M. Minkov, Kultury i organizacje, przekł. M. Durska, Warszawa 2011.

16 A.J. Macneil, D.L. Prater, S. Busch, The effects of school culture and climate on student achievement, International Journal of Leadership in Education, 2009, 1.

17 Tamże, s. 74. 


\section{Badania kultury szkoły}

W ostatnich latach obserwuje się wyraźny wzrost zainteresowania badaczy kulturą i klimatem szkoły. Niejasności definicyjne towarzyszące tym pojęciom sprawiają, że wielu z nich utożsamia klimat z kulturą szkoły, posługuje się tymi pojęciami zamiennie, co należy uznać za błędne podejście. Klimat szkoły bowiem implikuje czyjąś subiektywną ocenę środowiska szkolnego ${ }^{18}$. Kultura szkoły natomiast rozumiana jest jako swoista optyka, którą do oglądu siebie samych, innych oraz rzeczywistości przyjmują uczestnicy szkolnej społeczności ${ }^{19}$.

Polskie badania odwołujące się do myślenia o kulturze szkoły prowadzone są głównie wedle strategii badań jakościowych zorientowanych antropologicznie ${ }^{20}$. W ten sposób próbuje się rozpoznać swoistość szkoły. Analizy prowadzone są celem rekonstrukcji przyjętych $\mathrm{w}$ szkole wzorców zachowań, co z kolei daje podstawę do „pogłębionego, hermeneutycznie interpretatywnego rozumienia sensów nadawanych przez uczniów i nauczycieli szkolnej rzeczywistości"21. Takie podejście dostarcza niezwykle interesujących opisów życia codziennego poszczególnych szkół i ich interpretacji.

W podejściu ilościowym, by pogłębić zrozumienie kultury szkoły, korzysta się z doświadczeń badawczych teorii zarządzania, teorii organizacji i na ich podstawie, stosując właściwe im narzędzia, próbuje się umiejscowić, dopasować kultury szkół do typologii kultur czy klimatów organizacyjnych, a więc nadaje się im pewne etykiety analizując układ określonych cech charakterystycznych. Przykładem są badania opierające się na typologii kultur przedsiębiorstwa Kima Camerona i Roberta Quinna22, czy badania uwzględniające koncepcję Charlesa Handy'ego czterech kultur organizacji, opisane przez Romana Dorczaka ${ }^{23}$.

18 Por. A. Tłuściak-Deliowska, Klimat szkoty jako przedmiot badań. Wattpliwości i wyzwania, Ruch Pedagogiczny (w przygotowaniu).

19 Por. U. Dernowska, Kultura szkoty - pojęcie, wymiary, modele, Ruch Pedagogiczny (w przygotowaniu).

20 Por. B. Adrjan, Kultura szkoty. W poszukiwaniu nieuchwytnego, Kraków 2001; K. Polak, Kultura szkoty. Od relacji społecznych do języka uczniowskiego, Kraków 2007; A. Nalaskowski, Przestrzenie i miejsca szkoty, Kraków 2002; M. Dudzikowa, Mit o szkole jako miejscu wszechstronnego rozwoju ucznia. Eseje etnopedagogiczne, Kraków 2001.

${ }^{21}$ D. Klus-Stańska, Dzień jak co dzień. O barierach zmiany kultury szkoty, [w:] Wychowanie. Pojęcia, procesy, konteksty, red. M. Dudzikowa, M. Czerepaniak-Walczak, Gdańsk 2010, s. 307.

${ }^{22} \mathrm{~Np}$. E. Strutyńska, Mobbing wśród nauczycieli a kultura organizacji - relacja z badań, Kwartalnik Pedagogiczny (w przygotowaniu).

${ }^{23}$ R. Dorczak, Cechy kultury organizacyjnej szkoty w aspekcie reformy nadzoru pedagogicznego, [w:] Kultura organizacyjna szkoty rozwijającej się, red. E. Augustyniak, Kraków 2011, s. 265-270. 
Kulturę szkoły można badać także analizując poszczególne wymiary, elementy, czy obszary ją konstytuujące. Takie podejście dominuje w zagranicznych studiach empirycznych. Przykładem mogą być tutaj liczne badania amerykańskie ${ }^{24}$ czy studia europejskie, jak np. badania Ralfa Maslowskiego w Finlandii 25 lub studia azjatyckie, np. Ali Ilker Gumuseli i Arzu Eryilmaz badania prowadzone $\mathrm{w}$ Turcji ${ }^{26}$. Wykorzystuje się $\mathrm{w}$ nich narzędzia opracowane do badania explicite kultury szkoły. Podjęte przez nas studia empiryczne lokują się $w$ tym podejściu.

\section{Problem badawczy}

Badania zorientowano na charakterystykę nauczycielskiej percepcji sześciu wymiarów kultury współpracy w szkołach gimnazjalnych. Analizom poddano takie obszary kultury szkoły, jak: wspólne przywództwo, współpraca nauczycieli, możliwości ich rozwoju zawodowego, poczucie jedności celu, wzajemne wspieranie się nauczycieli, czy partnerstwo na rzecz uczenia się. Naszym celem nie było zatem przyporządkowanie "całej” szkoły do metaforycznie ujętego typu kultury szkoły. Już bowiem Edgar Schein podkreślał, że takie podejście jest „niepraktyczne”27. Interesowało nas raczej to, jaka jest struktura kultury współpracy w szkołach, a dokładniej jak badani nauczyciele postrzegaja sześć wymiarów kultury wspótpracy w szkole. Próbowałyśmy także ustalić, czy percepcja poszczególnych wymiarów jest specyficzna dla badanych szkót, a więc wewnętrznie spójna?

Eksponowane $\mathrm{w}$ artykule wyniki badań stanowią fragment wstępnych badań nad klimatem i kulturą szkół gimnazjalnych w percepcji nauczycieli.

${ }^{24} \mathrm{~Np}$. L. Olson, A study of school culture, leadership, teacher quality and student outcomes via a performance framework in elementary schools participating in a school reform initiative, 2009, Ph.D. dissertation, University of Florida; D.Y. Bruner, B.J. Greenlee, Analysis of school work culture in schools that implement comprehensive school reform models, Journal of Research for Educational Leaders, 2004, 2(3), s. 33-53; J.E. Quiambao, An analysis and comparison of school culture with academic achievement of middle school students with specific learning disabilities, 2004, Ph.D. dissertation, University of Central Florida.

${ }^{25}$ R. Maslowski, School Culture and School Performance. An Explorative Study into the Organizational Culture of Secondary Schools and Their Effects, 2001, Ph.D. thesis, University of Twente.

26 A.I. Gumuseli, A. Eryilmaz, The Measurement of Collaborative School Culture, s. 13-26.

${ }^{27}$ Cyt. za: S. Gruenert, Shaping a New School Culture, Contemporary Education, 2000, 71(2), s. 15 . 


\section{Metoda i procedura badania}

Charakterystyka badanych nauczycieli. W badaniu wzięło udział 74 nauczycieli z pięciu szkół gimnazjalnych w wieku od 25 lat do 59 (średnia wieku badanych: 42,29). Wśród nich było 46 kobiet (62,2\% całej próby) i 25 mężczyzn (33,8\%) (3 osoby nie podały informacji o swojej płci). Przewaga kobiet $\mathrm{w}$ badanej próbie potwierdza feminizację zawodu nauczycielskiego. Wszyscy badani nauczyciele mają wykształcenie wyższe (na poziomie inżyniera/licencjatu: 5,5\% badanych, na poziomie magistra: 94,5\%). Staż pracy badanych nauczycieli był od 3 do 34 lat. Większość badanej próby stanowią nauczyciele $\mathrm{z}$ najwyższymi stopniami awansu zawodowego, tj. nauczyciele dyplomowani $(61,1 \%)$, następnie nauczyciele mianowani $(26,4 \%)$, co pozwala uznać ich za posiadających duże doświadczenie zawodowe. 15,3\% badanych nauczycieli pracuje dodatkowo w innej szkole gimnazjalnej, a 23,6\% nauczycieli pracuje dodatkowo w szkole podstawowej. Prawie co czwarty nauczyciel $(23,9 \%)$ udziela prywatnych korepetycji.

Narzędzie. W badaniach wykorzystano narzędzie "School Culture Survey", opracowane przez Steve'a Gruenerta i Jerry'ego Valentine'a (1998). Narzędzie to jest stosowane $\mathrm{z}$ powodzeniem $\mathrm{w}$ wielu krajach do badania kultury szkoły ${ }^{28}$. Za zgodą autorów narzędzia przygotowano wersję polską kwestionariusza. Kwestionariusz zawiera ( $w$ wersji oryginalnej i w wersji polskiej) 35 pozycji. Mają one postać zdań twierdzących i opisują różne aspekty środowiska szkolnego oraz funkcjonowania pracowników szkoły. Każdy item oceniany jest na pięciopunktowej skali typu Likerta (od 1 do 5), gdzie: 1 oznacza: zdecydowanie się nie zgadzam; 2 - nie zgadzam się; 3 - nie mam zdania; 4 - zgadzam się; 5 - zdecydowanie się zgadzam. Liczba itemów przyporządkowanych do poszczególnych skal nie jest równa. Całość tworzy sześć skal, które obejmują: (1) przywództwo wspólne (PW; ang. collaborative leadership) (11 twierdzeń) - mierzy stopień, w jakim szkolni liderzy inicjują i podtrzymują relacje współpracy pomiędzy szkolnym personelem; (2) współpraca nauczycieli (WN; ang. teacher collaboration) (6 twierdzeń) mierzy stopień, $\mathrm{w}$ jakim nauczyciele angażują się w konstruktywny dialog, który służy tworzeniu edukacyjnej wizji szkoły; (3) rozwój zawodowy (RZ; ang. professional development) (5 twierdzeń) - mierzy stopien, w jakim nauczyciele cenią rozwój indywidualny i tym samym poprawę funkcjonowa-

${ }^{28}$ Np. K.G. Butucha, School Type and School Setting Differences in Teachers Perception of School Culture, International Journal of Education and Research, 2013, 1(12), s. 1-12; A.I. Gumuseli, A. Eryilmaz, The Measurement of Collaborative School Culture, s. 13-26; L. Olson, A study of school culture, 2009, Ph.D. dissertation, University of Florida. 
nia szkoły; (4) wzajemne/koleżeńskie wsparcie (WW; ang. collegial support) (4 twierdzenia) - mierzy stopień, w jakim nauczyciele efektywnie pracują razem. Skala obejmuje wzajemne zaufania nauczycieli, docenianie swoich pomysłów, wzajemną pomoc $\mathrm{w}$ trakcie pracy nad wykonaniem zadań organizacji szkoły; (5) jedność celu (JC; ang. unity of purpose) (5 twierdzeń) - mierzy stopień, $\mathrm{w}$ jakim nauczyciele podążają w stronę wspólnej dla szkoły misji oraz (6) partnerstwo na rzecz uczenia się (PU; ang. learning partnership) (4 twierdzenia) - mierzy stopień, w jakim nauczyciele, rodzice i uczniowie pracują razem dla wspólnego dobra uczniów.

Kwestionariusz w wersji polskiej charakteryzuje się korzystnymi parametrami psychometrycznymi. Zgodność wewnętrzna skal, obliczona metodą Cronbacha dla poszczególnych wymiarów, wyniosła od 0,65 do 0,94 (tylko jedna skala uzyskała współczynnik poniżej 0,70), co daje rezultat zbliżony do współczynników otrzymanych przez twórców narzędzia w warunkach amerykańskich: od 0,66 do 0,9129 i potwierdza, iż kwestionariusz ten może być stosowany do analizy i oceny kultury współpracy w szkole.

Przebieg badania. Wybrane do badania szkoły reprezentowały odmienne środowiska społeczne, mianowicie badania przeprowadzono $\mathrm{w}$ dwóch wiejskich małych szkołach gimnazjalnych (liczba mieszkańców w granicach 1-2 tys.), w gimnazjum gminy wiejskiej (do 10 tys. mieszkańców), gimnazjum małomiasteczkowym (do 50 tys. mieszkańców) oraz gimnazjum w dużym mieście (powyżej 200 tys. mieszkańców). Badanie przeprowadzono w szkołach gimnazjalnych, za uprzednią zgodą dyrektorów placówek. Ankiety do samodzielnego wypełnienia przez wszystkich nauczycieli danej placówki, w dogodnym dla nich czasie, dostarczono do szkół w kopertach. Przed przystąpieniem do wypełniania ankiet nauczyciele zostali poinformowani, że badanie jest całkowicie anonimowe, a jego wyniki posłużą wyłącznie celom naukowym (taka informacja była również zamieszczona w kopertach). Po dwóch tygodniach ankiety były odbierane ze szkól. Z dostarczonych 88 zestawów, wypełnione kwestionariusze w zaklejonych kopertach zwróciło 74 nauczycieli, co stanowi $84 \%$ badanej próby.

\section{Prezentacja i analiza wyników}

Kultura współpracy w szkole w percepcji badanych nauczycieli. Dla udokumentowania percepcji wyróżnionych wymiarów kultury szkoły przez

29 S. Gruenert, J. Valentine, Development of a school culture survey - unpublished doctoral dissertation, University of Missouri 1998. 
badanych nauczycieli zostaną przedstawione w tej części artykułu deskryptywne rozkłady odpowiedzi na poszczególne zdania opisujące funkcjonowanie szkoły.

Pierwszy wyróżniony wymiar kultury współpracy w szkole to tzw. wspólne przywództwo. Zawierają się w nim informacje o tym, czy dyrektor (dyrekcja) ceni pomysły nauczycieli, dąży do ich urzeczywistnienia, angażuje personel $\mathrm{w}$ proces podejmowania decyzji i ufa profesjonalnemu osądowi tegoż personelu. Ta kategoria obejmuje także takie zachowania, jak popieranie i nagradzanie podejmowania wyzwań i innowacyjnych pomysłów nauczycieli zorientowanych na poprawę edukacji uczniów, przywiązywanie wagi do dzielenia się pomysłami przez członków personelu i podejmowania wspólnych działań. „Wspólne przywództwo” oznacza zatem swoiste dzielenie przywództwa, umiejętne i elastyczne kierowanie oraz właściwą koordynację działań.

Odpowiedzi respondentów na pytania tworzące skalę „wspólne przywództwo" zestawione są w tabeli 1.

Tabela 1

„Wspólne przywództwo" w opinii nauczycieli

\begin{tabular}{|c|c|c|c|c|c|c|}
\hline \multicolumn{2}{|r|}{ Twierdzenie } & 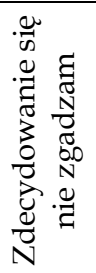 & 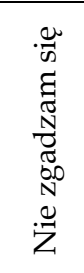 & 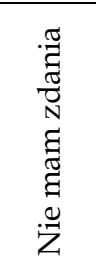 & 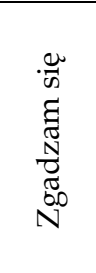 & 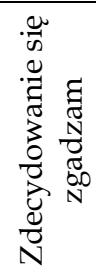 \\
\hline 2 & $\begin{array}{l}\text { Dyrekcja docenia pomysły i propo- } \\
\text { zycje nauczycieli }\end{array}$ & $2,7 \%$ & $2,7 \%$ & $14,9 \%$ & $54,1 \%$ & $25,7 \%$ \\
\hline 7 & $\begin{array}{l}\text { Dyrekcja polega na profesjonalnych } \\
\text { opiniach nauczycieli }\end{array}$ & 0 & $6,8 \%$ & $16,2 \%$ & $55,4 \%$ & $21,6 \%$ \\
\hline 11 & $\begin{array}{l}\text { Dyrekcja znajduje czas, żeby po- } \\
\text { chwalić nauczycieli za ich dobrą } \\
\text { pracę }\end{array}$ & $1,4 \%$ & $9,5 \%$ & $9,5 \%$ & $51,4 \%$ & $28,4 \%$ \\
\hline 14 & $\begin{array}{l}\text { Nauczyciele są zaangażowani w } \\
\text { proces podejmowania decyzji doty- } \\
\text { czących szkoły }\end{array}$ & $1,4 \%$ & $5,4 \%$ & $16,2 \%$ & $66,2 \%$ & $10,8 \%$ \\
\hline 18 & $\begin{array}{l}\text { Dyrekcja naszej szkoły ułatwia } \\
\text { współpracę między nauczycielami }\end{array}$ & $1,4 \%$ & $4,1 \%$ & $14,9 \%$ & $52,7 \%$ & $27,0 \%$ \\
\hline 20 & $\begin{array}{l}\text { Nauczyciele są informowani o bie- } \\
\text { żących sprawach szkoły }\end{array}$ & $2,7 \%$ & $6,8 \%$ & $4,1 \%$ & $64,9 \%$ & $21,6 \%$ \\
\hline 22 & $\begin{array}{l}\text { Moje zaangażowanie } \mathrm{w} \text { politykę } \\
\text { szkoły lub podejmowanie decyzji } \\
\text { jest poważnie traktowane }\end{array}$ & 0 & $5,4 \%$ & $24,3 \%$ & $54,1 \%$ & $16,2 \%$ \\
\hline
\end{tabular}




\begin{tabular}{|c|c|c|c|c|c|c|}
\hline & Twierdzenie & 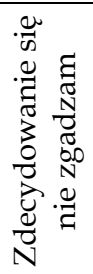 & 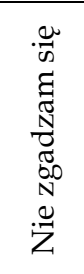 & 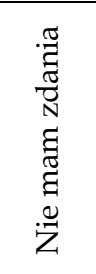 & 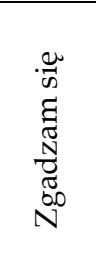 & 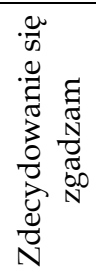 \\
\hline 26 & $\begin{array}{l}\text { Nauczyciele są nagradzani za eks- } \\
\text { perymentowanie (próbowanie; } \\
\text { sprawdzanie nowych koncepcji } \\
\text { i technik pracy) }\end{array}$ & $1,4 \%$ & $8,1 \%$ & $25,7 \%$ & $50,0 \%$ & $14,9 \%$ \\
\hline 28 & $\begin{array}{l}\text { Dyrekcja wspiera podejmowanie } \\
\text { ryzyka i innowacyjność w naucza- } \\
\text { niu }\end{array}$ & $2,7 \%$ & $4,1 \%$ & $21,6 \%$ & $59,5 \%$ & $12,2 \%$ \\
\hline 32 & $\begin{array}{l}\text { Administracja szkoły wspiera pro- } \\
\text { ces dydaktyczny i gospodarowanie } \\
\text { czasem pracy szkoły }\end{array}$ & $1,4 \%$ & $4,1 \%$ & $28,4 \%$ & $52,7 \%$ & $13,5 \%$ \\
\hline 34 & $\begin{array}{l}\text { Nauczyciele są zachęcani do dziele- } \\
\text { nia się swoimi pomysłami }\end{array}$ & $2,7 \%$ & $8,1 \%$ & $4,1 \%$ & $68,9 \%$ & $16,2 \%$ \\
\hline
\end{tabular}

Źródło: opracowanie własne.

$\mathrm{Na}$ podstawie danych zawartych $\mathrm{w}$ tabeli 1 możemy stwierdzić, że przeważająca część nauczycieli zgadza się z większością zawartych $\mathrm{w}$ tym wymiarze twierdzeń. Większość przyznaje, że dyrekcja docenia pomysły nauczycieli, ma zaufanie do swoich nauczycieli, chwali za dobrą pracę. Nauczyciele mają możliwość współdecydowania w ważnych kwestiach dotyczących funkcjonowania szkoły. Jednakże, w kwestii wspierania innowacyjności co piąty nauczyciel miał trudność z jednoznaczną odpowiedzią. Prawie co trzeci nauczyciel nie miał zdania w kwestii wsparcia pracy dydaktycznej i jej planowania przez administrację szkoły. Można zatem przypuszczać, że w tych obszarach współpraca jest niewystarczająca lub mało widoczna.

Z punktu widzenia tworzenia kultury współpracy w szkole, istotne jest, czy na płaszczyźnie zawodowej, obejmującej czynności dydaktycznowychowawcze, współpracują ze sobą sami nauczyciele. A zatem, istotne jest, czy nauczyciele opracowują wspólnie m.in. plan funkcjonowania szkoły, czy obserwują się wzajemnie i dyskutują o praktyce nauczania, czy potrafią sobie pomagać, czy gromadzą informacje o programach i rozwijają świadomość działania i programów realizowanych przez innych nauczycieli. Te kwestie zostały uwzględnione w kolejnym wymiarze kultury współpracy w szkole (patrz tab. 2). 
Tabela 2

Współpraca nauczycieli w opinii badanych

\begin{tabular}{|c|c|c|c|c|c|c|}
\hline & Twierdzenie & 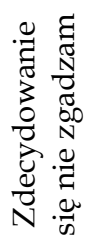 & 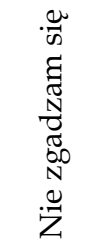 & 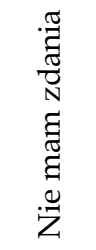 & 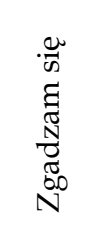 & 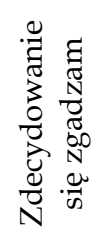 \\
\hline 3 & $\begin{array}{l}\text { Nauczyciele mają możliwość dialo- } \\
\text { gu i wspólnego planowania po- } \\
\text { szczególnych przedmiotów }\end{array}$ & $2,7 \%$ & $19,2 \%$ & $21,9 \%$ & $45,2 \%$ & $11,0 \%$ \\
\hline 8 & $\begin{array}{l}\text { Nauczyciele poświęcają znaczną } \\
\text { ilość czasu na wspólne planowanie } \\
\text { pracy dydaktyczno-wychowawczej }\end{array}$ & $1,4 \%$ & $9,5 \%$ & $14,9 \%$ & $63,5 \%$ & $10,8 \%$ \\
\hline 15 & $\begin{array}{l}\text { Nauczyciele znajdują czas, by móc } \\
\text { obserwować wzajemnie swoją pracę } \\
\text { dydaktyczną }\end{array}$ & $5,5 \%$ & $24,7 \%$ & $24,7 \%$ & $41,1 \%$ & $4,1 \%$ \\
\hline 23 & $\begin{array}{l}\text { Nauczyciele są na ogół świadomi } \\
\text { tego, jakiego przedmiotu uczą po- } \\
\text { zostali nauczyciele z ich szkoły }\end{array}$ & $1,4 \%$ & 0 & $2,7 \%$ & $35,1 \%$ & $60,8 \%$ \\
\hline 29 & $\begin{array}{l}\text { Nauczyciele współpracują ze sobą } \\
\text { w celu opracowywania programów } \\
\text { i projektów oraz ich ewaluacji }\end{array}$ & $1,4 \%$ & $5,5 \%$ & $8,2 \%$ & $64,4 \%$ & $20,5 \%$ \\
\hline 33 & $\begin{array}{l}\text { Różnice zdań dotyczące praktyki } \\
\text { nauczania wyrażane są otwarcie } \\
\text { i poddawane pod dyskusję }\end{array}$ & $1,4 \%$ & $9,5 \%$ & $24,3 \%$ & $52,7 \%$ & $12,2 \%$ \\
\hline
\end{tabular}

Źródło: opracowanie własne.

Nauczyciele $w$ badanych szkołach nie mają problemu ze zidentyfikowaniem przedmiotów, których uczą ich koledzy. Może wynikać to z faktu, że szkoły, które brały udział w badaniu były nieduże (ok. 20 pracowników), zatem nauczyciele mają $\mathrm{w}$ takich warunkach społecznych możliwość kontaktów "twarzą w twarz". Badani nauczyciele w większości przyznali, że poświęcają dużo czasu na wspólne planowanie pracy dydaktycznej oraz opracowywanie wspólnych projektów, ale tylko ponad 40\% znajduje czas, by obserwować pracę innych nauczycieli. Być może nauczyciele nie odczuwają takiej potrzeby lub nie dostrzegają $\mathrm{w}$ obserwacji pracy innych pożytków dla siebie. 
Na podstawie analizy literatury przedmiotu ${ }^{30}$ można przyjąć, że rozwój indywidualny nauczycieli jest początkiem drogi rozwoju całej szkoły. Szkoła jako „organizacja ucząca się" musi zwracać uwagę na przemyślany rozwój poszczególnych pracowników. Samym pracownikom, szczególnie w zawodzie nauczyciela, również powinno zależeć na ciągłym rozwoju osobistym i zawodowym. Wszakże potrzeba ustawicznego doskonalenia zawodowego stanowi właściwość pracy pedagogicznej i obejmuje zarówno aktualizowanie wiedzy, które wyznaczone jest postępem nauki, jak i doskonalenie kompetencji społecznych. Rozwój zawodowy nauczyciela jest istotny zarówno z punktu widzenia indywidualnego, jak i społecznego ${ }^{31}$. Powodzenie funkcjonowania szkoły jako całości jest bowiem zależne od powodzenia funkcjonowania jego części (czyli poszczególnych nauczycieli) i odwrotnie. Rozwój zawodowy nauczycieli stanowi zatem kolejny istotny obszar kultury współpracy w szkole.

Tabela 3

Rozwój zawodowy nauczycieli w opinii badanych

\begin{tabular}{|c|c|c|c|c|c|c|}
\hline & Twierdzenie & 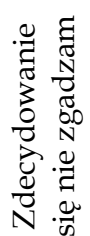 & 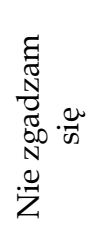 & 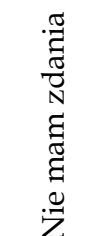 & 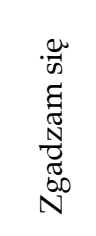 & 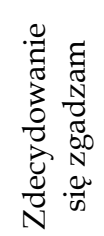 \\
\hline 1 & $\begin{array}{l}\text { Nauczyciele wykorzystują sieci } \\
\text { współpracy i samokształcenia } \\
\text { w celu pozyskiwania informacji } \\
\text { oraz pomysłów dla efektywniejsze- } \\
\text { go nauczania }\end{array}$ & 0 & $2,8 \%$ & $20,8 \%$ & $58,3 \%$ & $18,1 \%$ \\
\hline 9 & $\begin{array}{l}\text { Nauczyciele regularnie poszukują } \\
\text { inspiracji w konferencjach, semina- } \\
\text { riach oraz wśród kolegów - na- } \\
\text { uczycieli }\end{array}$ & $1,4 \%$ & $14,9 \%$ & $16,2 \%$ & $54,1 \%$ & $13,5 \%$ \\
\hline 16 & $\begin{array}{l}\text { Rozwój zawodowy jest doceniany } \\
\text { przez dyrekcję szkoły }\end{array}$ & $1,4 \%$ & $6,8 \%$ & $8,1 \%$ & $58,1 \%$ & $25,7 \%$ \\
\hline 24 & $\begin{array}{l}\text { Nauczyciele uwzględniają w swojej } \\
\text { pracy obecny stan wiedzy na temat } \\
\text { procesu uczenia }\end{array}$ & 0 & 0 & $16,4 \%$ & $53,4 \%$ & $30,1 \%$ \\
\hline
\end{tabular}

${ }^{30}$ Por. np. E. Augustyniak, Kultura organizacyjna szkoty jako organizacji uczacej się, [w:] Kultura organizacyjna szkoty, s. 160.

${ }^{31}$ S. Tucholska, Wypalenie zawodowe u nauczycieli. Psychologiczna analiza zjawiska i jego osobowościowych uwarunkowań, Lublin 2009, s. 96. 


\begin{tabular}{|c|c|c|c|c|c|c|}
\hline \multicolumn{2}{|r|}{ Twierdzenie } & 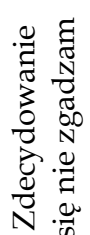 & 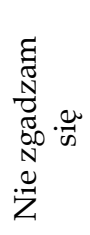 & 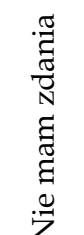 & 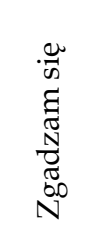 & 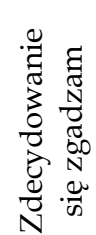 \\
\hline 30 & $\begin{array}{l}\text { Dla dyrekcji ważne jest doskonale- } \\
\text { nie jakości pracy szkoły }\end{array}$ & $1,4 \%$ & $2,7 \%$ & $4,1 \%$ & $43,8 \%$ & $47,9 \%$ \\
\hline
\end{tabular}

Źródło: opracowanie własne.

Jak wynika $\mathrm{z}$ danych zestawionych $\mathrm{w}$ tabeli 3, zdecydowana większość nauczycieli przyznała, że uwzględnia w swojej pracy obecny stan wiedzy na temat procesu kształcenia. Przyznanie się, że jest odwrotnie, że nie posiada się wystarczającej i aktualnej wiedzy merytorycznej podważyłoby sens pracy nauczycieli w tym zawodzie. Większość badanych dąży do rozwoju zawodowego poprzez czerpanie i poszukiwanie inspiracji oraz pomysłów do pracy z różnych źródeł (np. konferencje, seminaria, sieci współpracy itp.). Rozwój zawodowy nauczycieli doceniany jest przez dyrekcję szkół.

Tabela 4

„Jedność celu” w percepcji badanych nauczycieli

\begin{tabular}{|c|c|c|c|c|c|c|}
\hline \multicolumn{2}{|r|}{ Twierdzenie } & 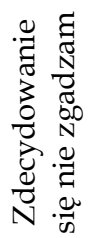 & 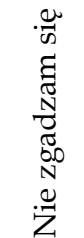 & 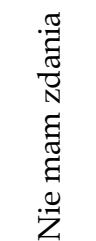 & 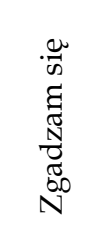 & 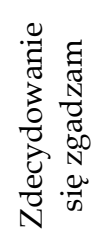 \\
\hline 5 & Nauczyciele wspierają misję szkoły & $1,4 \%$ & $5,5 \%$ & $11,0 \%$ & $64,4 \%$ & $17,8 \%$ \\
\hline 12 & $\begin{array}{l}\text { Misja szkoły nadaje wyraźny kieru- } \\
\text { nek działaniom nauczycieli }\end{array}$ & $1,4 \%$ & $6,8 \%$ & $23,0 \%$ & $59,5 \%$ & $9,5 \%$ \\
\hline 19 & Nauczyciele rozumieją misję szkoły & $4,1 \%$ & $4,1 \%$ & $18,9 \%$ & $60,8 \%$ & $12,2 \%$ \\
\hline 27 & $\begin{array}{l}\text { Założenia misji szkoły mają od- } \\
\text { zwierciedlenie w wartościach naszej } \\
\text { społeczności szkolnej }\end{array}$ & $1,4 \%$ & $4,1 \%$ & $14,9 \%$ & $67,6 \%$ & $12,2 \%$ \\
\hline 31 & $\begin{array}{l}\text { Osiągane efekty kształcenia od- } \\
\text { zwierciedlają misję szkoły }\end{array}$ & $1,4 \%$ & $4,2 \%$ & $22,5 \%$ & $57,7 \%$ & $14,1 \%$ \\
\hline
\end{tabular}

Źródło: opracowanie własne. 
Zdaniem Grzegorza Mazurkiewicza, bardzo dobre pomysły często nie mają szans na swoją realizację, szczególnie kiedy są produktem „pokawałkowanej" i fragmentarycznej rzeczywistości ${ }^{32}$. Ma to miejsce wówczas, gdy decyzje podejmowane są na różnych, niewspółpracujących ze sobą segmentach systemu, a następnie mają być realizowane przez ludzi, którzy pracują bez wcześniejszego ustalenia systemu wartości i priorytetów. Natomiast, kiedy uda się połączyć ludzi pracujących ze sobą wspólną wizją i poczuciem odpowiedzialności, wówczas pojawi się zaufanie i zaangażowanie. Z tego punktu widzenia niezwykle ważna staje się „jedność celu", kolejny wymiar kultury współpracy w szkole.

Z przedstawionych w powyższej tabeli rozkładów odpowiedzi wynika, że większość nauczycieli „podąża” w stronę wspólnej dla szkoły misji. Badani nauczyciele przyznali, że rozumieją, popierają i działają w zgodzie z tą misją.

Kolejny wyróżniony obszar kultury współpracy w szkole to ocena jakości relacji nauczycielskich. Z punktu widzenia efektywności szkoły ważne jest środowisko społeczne, w którym pracownicy czują się bezpiecznie i komfortowo. Satysfakcjonujące relacje interpersonalne $\mathrm{w}$ gronie pedagogicznym mogą zapewnić redukowanie napięć czy uzyskanie doraźnej pomocy w przypadku trudności zawodowych.

Tabela 5

Wzajemne/koleżeńskie wsparcie w ocenie badanych nauczycieli

\begin{tabular}{|c|c|c|c|c|c|c|}
\hline \multicolumn{2}{|r|}{ Twierdzenie } & 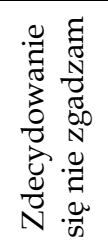 & 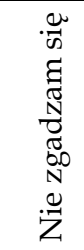 & 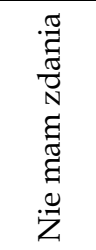 & 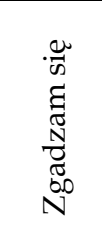 & 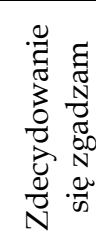 \\
\hline 4 & $\begin{array}{l}\text { Nauczyciele darzą się wzajemnym } \\
\text { zaufaniem }\end{array}$ & $4,1 \%$ & $6,8 \%$ & $24,3 \%$ & $50,0 \%$ & $14,9 \%$ \\
\hline 10 & $\begin{array}{l}\text { Nauczyciele są chętni do pomocy, } \\
\text { gdy pojawi się jakiś problem }\end{array}$ & $1,4 \%$ & $4,1 \%$ & $8,1 \%$ & $54,1 \%$ & $32,4 \%$ \\
\hline 17 & $\begin{array}{l}\text { Pomysły nauczycieli sa doceniane } \\
\text { przez innych nauczycieli }\end{array}$ & $1,4 \%$ & $8,1 \%$ & $17,6 \%$ & $64,9 \%$ & $8,1 \%$ \\
\hline 25 & $\begin{array}{l}\text { Nauczyciele współpracują ze sobą } \\
\text { w zespołach }\end{array}$ & $1,4 \%$ & $9,5 \%$ & $4,1 \%$ & $54,1 \%$ & $31,1 \%$ \\
\hline
\end{tabular}

Źródło: opracowanie własne.

${ }^{32}$ G. Mazurkiewicz, Przywództwo edukacyjne. Odpowiedzialne zarządzanie edukacja wobec wyzwań wspótczesności, Kraków 2011, s. 230. 
Ponad połowa badanych nauczycieli (patrz tab. 5) przyznała, że darzy się wzajemnym zaufaniem oraz jest chętna do pomocy innym współpracownikom. Większość stwierdziła, że współpracuje w zespole nauczycielskim. Prawie co piąty nauczyciel nie wie jednak, czy pomysły nauczycieli doceniane są przez kolegów.

Ostatni analizowany wymiar kultury współpracy w szkole dotyczy „partnerstwa” najważniejszych grup członków społeczności szkolnej, a więc nauczycieli, uczniów i rodziców. Twierdzenia w nim zawarte dotyczą wspólnych oczekiwań rodziców i nauczycieli, wzajemnej komunikacji na temat uczniowskich postępów, wzajemnego zaufania i przyjmowania odpowiedzialności za proces uczenia się.

Tabela 6

„Partnerstwo na rzecz uczenia się"

\begin{tabular}{|c|c|c|c|c|c|c|}
\hline & Twierdzenie & 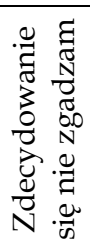 & 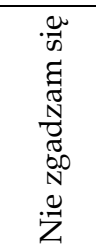 & 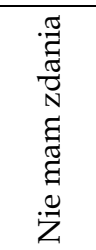 & 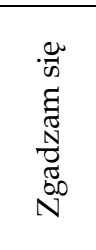 & 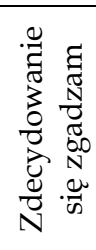 \\
\hline 6 & $\begin{array}{l}\text { Nauczyciele i rodzice mają tożsame } \\
\text { oczekiwania dotyczące osiągnięć } \\
\text { uczniów }\end{array}$ & $5,5 \%$ & $27,4 \%$ & $27,4 \%$ & $34,2 \%$ & $5,5 \%$ \\
\hline 13 & $\begin{array}{l}\text { Rodzice mają zaufanie do profesjo- } \\
\text { nalnych osądów formułowanych } \\
\text { przez nauczycieli }\end{array}$ & $4,1 \%$ & $12,2 \%$ & $48,6 \%$ & $32,4 \%$ & $2,7 \%$ \\
\hline 21 & $\begin{array}{l}\text { Nauczyciele rozmawiają często } \\
\text { z rodzicami o wynikach ich dzieci }\end{array}$ & $4,1 \%$ & $10,8 \%$ & 0 & $66,2 \%$ & $18,9 \%$ \\
\hline 35 & $\begin{array}{l}\text { Uczniowie tej szkoły w większości } \\
\text { przyjmują odpowiedzialność za } \\
\text { swoją naukę, co wyraża się np. } \\
\text { w zaangażowaniu w pracę umy- } \\
\text { słową podczas lekcji i odrabianiu } \\
\text { zadań domowych }\end{array}$ & $6,8 \%$ & $18,9 \%$ & $24,3 \%$ & $48,6 \%$ & $1,4 \%$ \\
\hline
\end{tabular}

Źródło: opracowanie własne

Rozkład odpowiedzi nauczycieli na twierdzenia przedstawione w tabeli 6 jest dość niejednorodny. Większość (ok. 80\%) potwierdza, że rozmawia $\mathrm{z}$ rodzicami o wynikach ich dzieci. Jednakże, tylko co trzeci nauczyciel przyznaje, że oczekiwania rodziców i nauczycieli dotyczące osiągnięć ich 
uczniów są spójne, a prawie połowa $(48,6 \%)$ badanych nie wie, czy rodzice mają zaufanie do formułowanych przez nauczycieli opinii. Taki stan rzeczy może świadczyć o tym, że komunikacja w relacji nauczyciel - rodzic jest jednostronna i sprowadza się jedynie do komunikowania rodzicom wyników osiąganych przez ich dzieci, a zatem $\mathrm{w}$ tej relacji miejsce dialogu zajmuje nauczycielski monolog.

Należy także zwrócić uwagę, że ta skala („partnerstwo na rzecz uczenia się") uzyskała najniższy współczynnik rzetelności i należałoby ją dopracować.

Zaprezentowany poniżej wykres służy podsumowaniu prowadzonych dotąd analiz i przedstawia średnie wartości dla poszczególnych skal kultury szkoły uzyskane w badaniach.

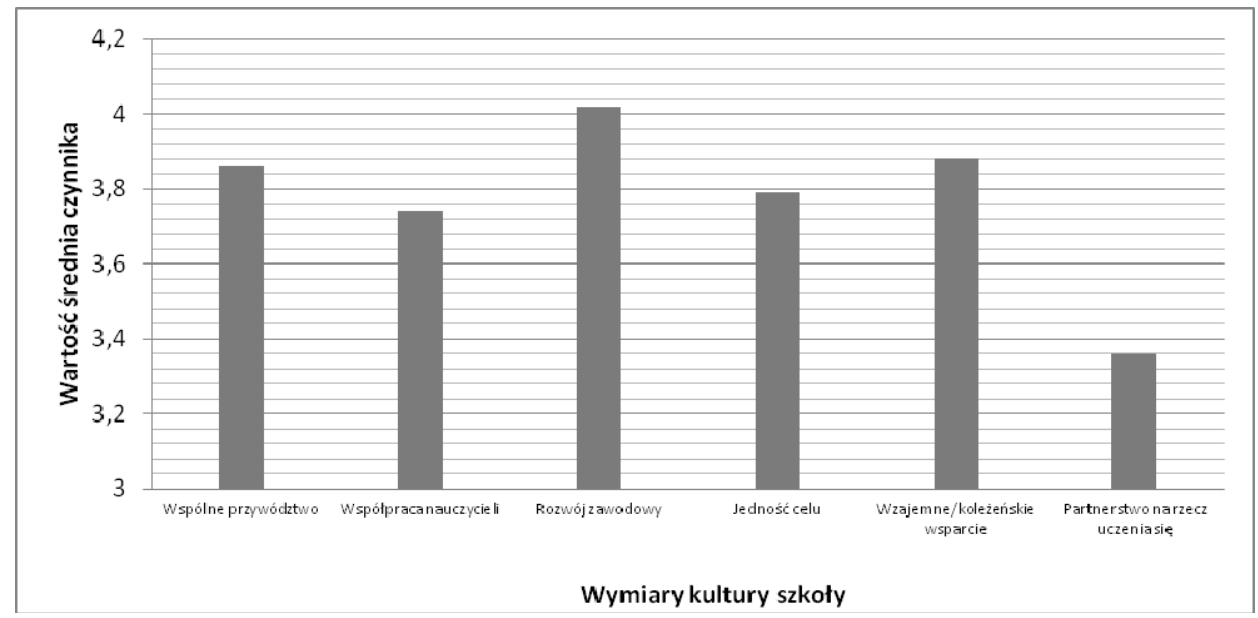

Ryc. 1. Percepcja poszczególnych wymiarów kultury współpracy w szkołach przez badanych nauczycieli $(\mathrm{N}=74)$

Wyraźnie widać więc, że najwyżej oceniono „rozwój zawodowy”, za znaczące nauczyciele uznali także takie wymiary kultury szkoły, jak „wzajemne/koleżeńskie wsparcie” czy „wspólne przywództwo”, a więc kategorię świadczącą o chęci dzielenia z dyrekcją odpowiedzialności za szkołę, potrzebie współdecydowania o tym, co w niej się dzieje, a także o woli współpracy. Najniżej natomiast badani nauczyciele ocenili „partnerstwo na rzecz uczenia się", a więc wspólną pracę z rodzicami i uczniami, zorientowaną na budowanie środowiska uczenia się sprzyjającego wysokim osiągnięciom dydaktycznym uczniów, odnoszeniu przez nich sukcesów w nauce. 
Dla oszacowania wzajemnych zależności pomiędzy poszczególnymi wymiarami kultury szkoły obliczono korelacje. Tak powstała macierz współczynników korelacji podana w tabeli 7.

Tabela 7

Matryca interkorelacji wymiarów kultury szkoły

\begin{tabular}{|l|c|c|c|c|c|c|}
\hline & $(1)$ & $(2)$ & $(3)$ & $(4)$ & $(5)$ & $(6)$ \\
\hline (1) Przywództwo wspólne & 1 & 0,81 & 0,82 & 0,42 & 0,87 & 0,59 \\
\hline (2) Współpraca nauczycieli & & 1 & 0,73 & 0,45 & 0,79 & 0,68 \\
\hline (3) Rozwój zawodowy & & & 1 & 0,35 & 0,76 & 0,49 \\
\hline $\begin{array}{l}\text { (4) Wzajemne/koleżeńskie } \\
\text { wsparcie }\end{array}$ & & & & 1 & 0,77 & 0,34 \\
\hline (5) Jedność celu & & & & & 1 & 0,64 \\
\hline $\begin{array}{c}\text { (6) Partnerstwo na rzecz uczenia } \\
\text { się }\end{array}$ & & & & & 1 \\
\hline
\end{tabular}

Wszystkie korelacje przedstawione $\mathrm{w}$ tabeli są istotne na poziomie $\mathrm{p}<0,01$ (dwustronnie).

Źródło: opracowanie własne.

Ocena większości analizowanych wymiarów kultury współpracy w szkole jest ze sobą skorelowana na poziomie przeciętnym i wysokim. Wartości korelacji zawierają się $\mathrm{w}$ przedziale od 0,34 do 0,87 . Względnie niskie korelacje wymiaru „wzajemne/koleżeńskie wsparcie” z innymi wymiarami mogą wskazywać na jego niezależność i może, naszym zdaniem, świadczyć to bardziej o przynależności do kategorii klimatu społecznego szkoły (jakość relacji społecznych) niż do kultury szkoły.

Międzyszkolne zróżnicowanie kultury współpracy. Jeśli postrzeganie kultury współpracy wewnątrz danej szkoły jest względnie jednorodne wśród jej członków (czyli postrzegają ją podobnie), zaś różnice występują pomiędzy szkołami, można wówczas powiedzieć, iż mamy do czynienia ze swego rodzaju fenomenem społecznym, a mianowicie $\mathrm{z}$ istnieniem kultury szkoły, która jest specyficzna dla danej placówki.

W celu ustalenia, na ile percepcja poszczególnych elementów kultury szkoły jest specyficzna dla poszczególnych szkół, przeprowadzono jednoczynnikową analizę wariancji. Jej rezultaty przedstawiono w tabeli 8 .

W przypadku dwóch wymiarów kultury współpracy w szkole odnotowano istotne zróżnicowanie między szkołami. Różnice średnich były istotne na poziomie $\mathrm{p}<0,01 \mathrm{w}$ przypadku wymiaru „wspólne przywództwo" $\left(F_{(3,70)}\right.$ $=4,52)$, natomiast na poziomie $\mathrm{p}<0,05 \mathrm{w}$ przypadku wymiaru ,jedność celu" $\left(F_{(3,66)}=3,31\right)$. Możemy zatem powiedzieć, że te dwa obszary kultury współpracy w szkole mogą być specyficzne dla różnych szkół. 
Tabela 8

Zróżnicowanie percepcji poszczególnych wymiarów kultury szkoły w zależności od typu szkoły (analiza wariancji)

\begin{tabular}{|c|c|c|c|c|c|c|}
\hline \multicolumn{2}{|c|}{ Wymiar kultury szkoły } & $\begin{array}{c}\text { Suma } \\
\text { kwadratów }\end{array}$ & $d f$ & $\begin{array}{l}\text { Średni } \\
\text { kwadrat }\end{array}$ & $F$ & Istotność \\
\hline \multirow{3}{*}{ Wspólne przywództwo } & $\begin{array}{l}\text { między } \\
\text { grupami }\end{array}$ & 5,123 & 3 & 1,708 & 4,524 & ,006 \\
\hline & $\begin{array}{l}\text { wewnątrz } \\
\text { grup }\end{array}$ & 26,418 & 70 & ,377 & & \\
\hline & ogółem & 31,540 & 73 & & & \\
\hline \multirow{3}{*}{$\begin{array}{l}\text { Współpraca } \\
\text { nauczycieli }\end{array}$} & $\begin{array}{l}\text { między } \\
\text { grupami }\end{array}$ & 2,372 & 3 & 791 & 2,207 & ,095 \\
\hline & $\begin{array}{l}\text { wewnątrz } \\
\text { grup }\end{array}$ & 24,007 & 67 & ,358 & & \\
\hline & ogółem & 26,379 & 70 & & & \\
\hline \multirow{3}{*}{ Rozwój zawodowy } & $\begin{array}{l}\text { między } \\
\text { grupami }\end{array}$ & 2,377 & 3 & 792 & 2,633 & ,057 \\
\hline & $\begin{array}{l}\text { wewnątrz } \\
\text { grup }\end{array}$ & 20,163 & 67 & ,301 & & \\
\hline & ogółem & 22,540 & 70 & & & \\
\hline \multirow{3}{*}{ Jedność celu } & $\begin{array}{l}\text { między } \\
\text { grupami }\end{array}$ & 4,375 & 3 & 1,458 & 3,303 & ,026 \\
\hline & $\begin{array}{l}\text { wewnątrz } \\
\text { grup }\end{array}$ & 29,142 & 66 & ,442 & & \\
\hline & ogółem & 33,518 & 69 & & & \\
\hline \multirow{3}{*}{$\begin{array}{l}\text { Wzajemne/koleżeńskie } \\
\text { wsparcie }\end{array}$} & $\begin{array}{l}\text { między } \\
\text { grupami }\end{array}$ & 1,538 & 3 & ,513 & 1,158 & ,332 \\
\hline & $\begin{array}{l}\text { wewnątrz } \\
\text { grup }\end{array}$ & 30,993 & 70 & ,443 & & \\
\hline & ogółem & 32,530 & 73 & & & \\
\hline \multirow{3}{*}{$\begin{array}{l}\text { Partnerstwo na rzecz } \\
\text { uczenia się }\end{array}$} & $\begin{array}{l}\text { między } \\
\text { grupami }\end{array}$ & 1,089 & 3 & 363 & ,918 & 437 \\
\hline & $\begin{array}{l}\text { wewnątrz } \\
\text { grup }\end{array}$ & 27,285 & 69 & ,395 & & \\
\hline & ogółem & 28,373 & 72 & & & \\
\hline
\end{tabular}

Źródło: opracowanie własne.

W przypadku wymiarów „współpraca nauczycieli” $\left(F_{(3,67)}=2,21\right)$ oraz „rozwój zawodowy” $\left(F_{(3,67)}=2,63\right)$ odnotowano różnice na poziomie tendencji statystycznej $(\mathrm{p}<0,1)$. Takie wyniki mogą wskazywać na pewne zróżnicowanie między szkołami, które w innych warunkach, np. przy większej próbie, mogłoby być istotne statystycznie. 


\section{Zakończenie}

Wydaje się, że dydaktyczna samotność w szkole jest częstym doświadczeniem wielu nauczycieli, którzy w procesie kształcenia czują się zdani wyłącznie na siebie - w pojedynkę poszukują lepszych, ich zdaniem, metodycznych rozwiązań lekcji czy efektywniejszych strategii nauczania. W pojedynkę zmagają się z doświadczanymi problemami, z własną niewiedzą, do której, ich zdaniem, nie wolno się przyznać. W pojedynkę wreszcie podejmują kolejne wyzwania wpisane $\mathrm{w}$ rolę nauczyciela, a więc bez jakiegokolwiek wsparcia ze strony dyrekcji czy innych nauczycieli33. Tak jednak być nie musi i nie może, zwłaszcza że dzisiejszej edukacji potrzebne jest

nowoczesne przewodzenie, polegające na współdziałaniu i permanentnej komunikacji z ludźmi, sprawnie wykorzystujące skomplikowaną różnorodność działań, postaw, zachowań i wartości obecną w każdej organizacji33

Konieczne jest zatem przewodzenie, które stanowi proces podejmowania działań, kreowania sytuacji uprawniających innych do działania, modelowania relacji między nauczycielami. Takie „wspólne przewodzenie” zrozumieć można tylko w kontekście relacyjnym, w otoczeniu szkolnym.

Szkoła może realizować swoje cele tylko dzięki skoordynowanej współpracy różnych jej pracowników. Efektywne jej funkcjonowanie i sukcesy uwarunkowane są pracą nie tyle pojedynczych nauczycieli, co raczej całego zespołu nauczycielskiego, wspólnie z dyrekcją. Współpraca stwarza lepsze warunki do wprowadzania innowacji 35 . W takich warunkach mogą pojawić się różne interpretacje tego samego rozwiązania, możliwość dyskutowania i omawiania nowych pomysłów, a także wykorzystania potencjału wszystkich członków zespołu. Panująca kultura współpracy może wzmacniać poczucie bezpieczeństwa członków społeczności szkolnej, a także stymulować pomysłowość nauczycieli.

To, w jaki sposób badani nauczyciele szkół gimnazjalnych postrzegają wybrane aspekty kultury szkoły pozwala sądzić, że sami nauczyciele dostrzegają wagę współpracy i jej znaczenie nie tylko dla funkcjonowania szkoły jako instytucji, której działania ukierunkowane są na jasno sprecyzowane cele kształcenia, ale także dla rozwoju zawodowego i personalnego

${ }^{33}$ U. Dernowska, Profesjonalna wiedza nauczyciela - źródta i sposoby eksploatacji, Ruch Pedagogiczny, 2012, 3 .

${ }^{34}$ G. Mazurkiewicz, Przywództwo edukacyjne, s. 46.

${ }_{35}$ M. Wiśniewska, Subkultura zespotów nauczycielskich w kulturze szkoty rozwijającej się, [w:] Kultura organizacyjna szkoty, s. 78. 
osób, które na co dzień zajmują się nauczaniem. Przeprowadzone badania pozwalają na konkluzję, że o ile nauczyciele uświadamiają sobie potrzebę budowania kultury współpracy w obrębie szkoły, o tyle ich troska o partnerstwo z rodzicami czy uczniami jest $\mathrm{w}$ badanych szkołach wciąż niewystarczająca.

\section{BIBLIOGRAFIA}

Adrjan B., Kultura szkoty. W poszukiwaniu nieuchwytnego, Oficyna Wydawnicza Impuls, Kraków 2001.

Augustyniak E., Kultura organizacyjna szkoty jako organizacji uczacej się, [w:] Kultura organizacyjna szkoty rozwijającej się, red. E. Augustyniak, Wydawnictwa AGH, Kraków 2011.

Brankovic N., Rodić V., Determination of Indicators of School Culture in Primary Schools, The New Educational Review, 2012, 3.

Bruner D.Y., Greenlee B.J., Analysis of school work culture in schools that implement comprehensive school reform models, Journal of Research for Educational Leaders, 2004, 2(3).

Butucha K.G., School Type and School Setting Differences in Teachers Perception of School Culture, International Journal of Education and Research, 2013, 1(12).

Dernowska U., Profesjonalna wiedza nauczyciela - źródła $i$ sposoby eksploatacji, Ruch Pedagogiczny, 2012, 3.

Dernowska U., Kultura szkoty - pojęcie, wymiary, modele, Ruch Pedagogiczny (w przygotowaniu).

Dorczak, R., Cechy kultury organizacyjnej szkoty w aspekcie reformy nadzoru pedagogicznego, [w:] Kultura organizacyjna szkoły rozwijającej się, red. E. Augustyniak, Wydawnictwa AGH, Kraków 2011.

Dudzikowa M., Mit o szkole jako miejscu wszechstronnego rozwoju ucznia. Eseje etnopedagogiczne, Oficyna Wydawnicza Impuls, Kraków 2001.

Fisher D., Frey N., Pumpian I., How to Create a Culture of Achievement in your School and Classroom, ASCD, Alexandria 2012.

Gruenert S., Shaping a New School Culture, Contemporary Education, 2000, 71 (2).

Gruenert S., Valentine J., Development of a school culture survey - unpublished doctoral dissertation, University of Missouri 1998.

Gumuseli A.I., Eryilmaz A., The Measurement of Collaborative School Culture (CSC) on Turkish Schools, New Horizons in Education, 2011, 59(2).

Hofstede G., Hofstede G.J., Minkov M., Kultury i organizacje, przekł. M. Durska, Polskie Wydawnictwo Ekonomiczne, Warszawa 2011.

Klus-Stańska D., Dzień jak co dzień. O barierach zmiany kultury szkoty, [w:] Wychowanie. Pojęcia, procesy, konteksty, red. M. Dudzikowa, M. Czerepaniak-Walczak, Gdańskie Wydawnictwo Psychologiczne, Gdańsk 2010.

Macneil A.J., Prater D.L., Busch S., The effects of school culture and climate on student achievement, International Journal of Leadership in Education, 2009, 1.

Maslowski R., School Culture and School Performance. An Explorative Study into the Organizational Culture of Secondary Schools and Their Effects, Ph.D. thesis, University of Twente 2001. 
Maslowski R., A Review of Inventories for Diagnosing School Culture, Journal of Educational Administration, 2006, 44(1).

Mazurkiewicz G., Przywództwo edukacyjne. Odpowiedzialne zarządzanie edukacja wobec wyzwań wspótczesności, Wydawnictwo UJ, Kraków 2011.

Nalaskowski A., Przestrzenie i miejsca szkoty, Oficyna Wydawnicza Impuls, Kraków 2002.

Olson L., A study of school culture, leadership, teacher quality and student outcomes via a performance framework in elementary schools participating in a school reform initiative, Ph.D. dissertation, University of Florida 2009.

Polak K., Kultura szkoły. Od relacji społecznych do języka uczniowskiego, Wydawnictwo UJ, Kraków 2007.

Przyborowska B., Kultura organizacyjna oświaty w zmiennym otoczeniu, Wyższa Szkoła Informatyki i Ekonomii TWP, Olsztyn 2007.

Quiambao J.E., An analysis and comparison of school culture with academic achievement of middle school students with specific learning disabilities, Ph.D. dissertation, University of Central Florida 2004.

Ramsey R.D., Don't Teach the Canaries not to Sing, Corwin Press, Thousand Oaks 2008.

Schoen L.T., Teddlie C., A new model of school culture: a response to a call for conceptual clarity, School Effectiveness and School Improvement, 2008, 19(2).

Strutyńska E., Mobbing wśród nauczycieli a kultura organizacji - relacja z badań, Kwartalnik Pedagogiczny (w przygotowaniu).

Tłuściak-Deliowska A., Klimat szkoty jako przedmiot badań. Watpliwości i wyzwania, Ruch Pedagogiczny (w przygotowaniu).

Tucholska S., Wypalenie zawodowe u nauczycieli. Psychologiczna analiza zjawiska i jego osobowościowych uwarunkowań, Wydawnictwo KUL, Lublin 2009.

Tuohy D., Dusza szkoty, przekł. K. Kruszewski, Wydawnictwo Naukowe PWN, Warszawa 2002.

Wiśniewska M., Subkultura zespołów nauczycielskich w kulturze szkoły rozwijającej się, [w:] Kultura organizacyjna szkoty rozwijającej się, red. E. Augustyniak, Wydawnictwa AGH, Kraków 2011. 